\title{
BACE1 and Presenilin: Two Unusual Aspartyl Proteases Involved in Alzheimer's Disease
}

\author{
Diana-Ines Dominguez Dieter Hartmann Bart De Strooper
}

Neuronal Cell Biology and Gene Transfer Laboratory, Department of Human Genetics, KU Leuven and VIB4, Leuven, Belgium

\section{Key Words}

Alzheimer's disease $\cdot$ Knockout mice $\cdot \beta$-Secretase . $\gamma$-Secretase

\begin{abstract}
Two enzymatic activities are required to generate the pathogenic $\beta$-amyloid $(A \beta)$ peptide that accumulates in the brain of Alzheimer's disease patients. Both activities are carried out by two unusual aspartyl proteases known as $\beta$ - and $\gamma$-secretase. Their therapeutic inhibition appears, therefore, a promising strategy to treat the disease. Transgenic mouse models in which the genes encoding the secretases have been ablated offer an invaluable tool, on the one hand, to gain more insights into the biological function of these proteases and, on the other hand, to predict the consequences that might be associated with enzyme inhibition in vivo.
\end{abstract}

Copyright ( 2004 S. Karger AG, Basel

Two unusual aspartyl proteases are implicated in Alzheimer's disease (AD). These are BACE1 [1] and the presenilins (PS) 1 and 2 [2] and they perform the two consecutive cleavages of the amyloid precursor protein (APP) required to generate the toxic $\beta$-amyloid $(\mathrm{A} \beta)$ peptide. First, BACE1 cuts APP, a type I transmembrane protein, at the $\beta$-site in the ectodomain 28 amino acids from the

\section{KARGER}

Fax + 41613061234

E-Mail karger@karger.ch

www. karger.com
(C) 2004 S. Karger AG, Basel

$1660-2854 / 04 / 0015-0168 \$ 21.00 / 0$

Accessible online at: www. karger.com/ndd transmembrane region. BACE1 is an aspartyl protease that is unusual in that it contains a carboxy-terminal extension that harbors a transmembrane domain [3-6]. The enzyme is by itself necessary and sufficient to perform the cleavage. The BACE1-generated APP C-terminal fragment that remains membrane-bound is subsequently cleaved by a PS-containing $\gamma$-secretase complex at the $\gamma$-site within the transmembrane domain [7]. Although several membrane proteins have been shown to be processed within their transmembrane regions, it is not yet clear how hydrolysis can take place within the hydrophobic milieu of the membrane [8-11]. In addition to this unusual enzymatic property, PS-dependent cleavage, contrary to $\beta$-cleavage, requires the function of at least three additional proteins, Nicastrin [12], Pen-2 [13] and Aph-1 [14], that together with PS form the active $\gamma$-complex [1517]. Despite the fact that direct proof that purified PS functions as a protease in vitro is still missing, many lines of evidence point strongly to PS as genuine aspartyl proteases [discussed extensively in 16, 18, 19]. The role played by the other components of the $\gamma$-complex in the cleaving reaction remains to be determined.

Alternatively to the BACE1/PS or $\beta / \gamma$-processing of APP that is known as 'amyloidogenic' since it results in A $\beta$ formation, APP can be cleaved by $\alpha / \gamma$-secretases in a nonamyloidogenic pathway. $\alpha$-Secretases are membranebound metalloproteases that belong to the ADAM (a disintegrin and metalloprotease) family [20-22]. They cleave
Diana-Ines Dominguez

Molecular Genetics Section, VIB4, Departement Menselijke Erfelijkheid, O. \& N Herestraat 49, bus 602, BE-3000 Leuven (Belgium)

Tel. +32 16 345878, Fax +3216 347181

E-Mail Diana-Ines.Dominguez@med.kuleuven.ac.be 
APP between the amino acids lysine 16 and leucine 17 of the $A \beta$ domain (numbers are given considering the first amino acid of $A \beta$ as position 1 ), therefore limiting $A \beta$ formation. The membrane-bound carboxy-terminal fragment of APP is subsequently processed within the transmembrane domain by $\gamma$-secretase resulting in the secretion of $\mathrm{p} 3$, a small peptide that lacks the amino-terminal 16 amino acids of $A \beta$.

\section{v-Secretase as Therapeutic Target}

Because the activity of $\beta$ - and $\gamma$-secretases is required to generate the pathogenic $A \beta$ peptide, inhibitors of these enzymes are potential therapeutic drugs to treat AD. Therefore, understanding the biological functions of these two unusual proteases and defining their natural substrates is enormously interesting not only from a purely basic scientific point of view, but in addition it is also crucial for the development of $\mathrm{AD}$ therapies aimed at lowering $A \beta$.

The physiological role of PSs has been extensively investigated in Caenorhabditis elegans, Drosophila melanogaster and Mus musculus. Deficiencies in PS genes cause severe lethal phenotypes that closely resemble those observed upon inactivation of the Notch signaling pathway [23]. Even partially deficient PS1 \pm PS2-/- mice that display an overall reduction in $\gamma$-secretase activity develop in adulthood a strong autoimmune phenotype [24]. The similarity in phenotypes of PS- and Notch-deficient animals can be explained by the fact that Notch receptors are substrates of $\gamma$-secretase and $\gamma$-cleavage is required to release the Notch intracellular domain from the membrane, which subsequently translocates into the nucleus and regulates gene transcription. The Notch pathway is responsible for complex cell fate decisions that occur during embryogenesis but also in adult life during $T$ cell differentiation $[25,26]$ and neurite remodeling in the central nervous system [27]. Moreover, Notch and APP are not the only substrates for $\gamma$-secretase; in fact there is a growing list of type I transmembrane proteins that are processed by PS within their transmembrane regions. All the above data suggest that therapeutic inhibition of $\gamma$ secretase may lead to undesirable toxic side effects and, indeed, administration of a potent $\gamma$-secretase inhibitor to mice, beyond the expected decrease in plasma and brain $\mathrm{A} \beta$ levels, also resulted in marked defects in lymphocyte development and in the intestine villi and mucosa, most probably due to an inhibition of Notch processing [28]. The possibility, however, still exists of developing alterna- tive drugs that rather than targeting the catalytic site of $\gamma$-secretase and thus affecting the cleavage of all substrates would specifically act on APP cleavage [81].

\section{ß-Secretase as Therapeutic Target}

Unlike PS, genetic ablation of the BACE1 gene in mice is not associated with any gross phenotype [29-31], even in aged animals [32]. The only phenotype described thus far is some indicator of anxiety detected recently in more specific behavioral tests [33]. Moreover, BACE1 deficiency could prevent the learning and memory impairments and the cholinergic dysfunction observed in a transgenic mouse model for AD [34]. Whereas all these data highlight the therapeutic potential of BACE1 inhibition, important questions still need to be addressed to better predict the functional consequences (if any) of this action.

Several lines of evidence suggest that APP is not the only and probably not the main substrate for BACE1. First, the two proteins localize to different subcellular compartments in polarized cells limiting the access of BACE1 to its substrate. Whereas most BACE1 goes apically, the bulk of APP is sorted basolaterally [35]. Artificially targeting APP to the apical surface was sufficient to increase $\beta$-processing and $A \beta$ generation. Similarly, the efficiency of BACE1 cleavage could be improved in nonpolarized cells by increasing the relative exposure of the substrate APP to BACE1 via its targeting to the endosomal compartment [36]. Second, the cleavage site in APP is not optimal and artificial sequences have been found that are processed far more efficiently not only than wild-type APP but also than APP carrying the Swedish familiar Alzheimer (FAD) mutation already known to be a better substrate for BACE1 [37]. It is, therefore, reasonable to assume that additional BACE1 substrates exist that are processed more efficiently than APP. Indeed two new substrates have been described for BACE1: P-selectin glycoprotein ligand-1 (PSGL-1) [38] and the sialyl transferase ST6Gal [39]. Both proteins are membrane-bound, as expected for a BACE1 substrate, and both have been ascribed a role in immune responses [40-42]. The evidence that they are substrates for BACE1 comes mainly from experiments in cultured cells, in conditions where both enzyme and substrate were overexpressed. Yet, whether these cleavages occur in vivo and their physiological significance, if any, remain to be determined. If PSGL-1 and ST6Gal are relevant physiological substrates of BACE1 and if their function is linked to the immune system, then the lack of any specific defect in BACE1- 
deficient animals may simply reflect the specific pathogen-free conditions in which mice are housed. Alternatively, genetic redundancy and the activation of compensatory mechanisms could also account for the absence of phenotype in BACE1 null mice. No significant compensatory mechanism seems to be activated in brain for APP cleavage [29-31]; however, this result does not exclude the possibility that compensatory mechanisms operate to cleave other substrate(s). Resolving this issue is important because putative compensatory mechanisms activated during embryogenesis might not operate in the elderly when chronic BACE1 inhibition is considered as a treatment for AD.

Shortly after the discovery of BACE1, a homologous gene has been identified by database search and named BACE2 [6, 43-45]. BACE2 encodes a membrane-bound aspartyl protease that is $68 \%$ similar to BACE1 at the amino acid level and that can process APP at the $\beta$-site. BACE2 is then the nearest BACE1 homologue, but besides their amino acid homology and their common structural organization, the two enzymes differ in their tissue distribution [45-47], subcellular localization [48] and substrate specificity $[45,48,49]$. BACE2 is ubiquitously expressed in fetal and adult tissues, although the enzyme levels in brain are low [44, 45, 47]. Whether BACE2 affects, positively or negatively, the $A \beta$ pool is a subject of debate. A positive contribution of BACE2 to brain A $\beta$ levels has been suggested in two pathological conditions. First, because the BACE2 gene is located in the Down syndrome critical region of chromosome 21 , it has been speculated that upregulation of BACE2 expression could be at least partially responsible for the higher levels of $A \beta$ and the development of the AD-like neuropathology associated with this syndrome $[43,47,50]$. Second, based on the observation that BACE2 cleavage of APP at the $\beta$-site is more efficient when APP carries the Flemish FAD mutation, it has been proposed that BACE2-mediated APP cleavage might play a role in the development of AD in individuals carrying this mutation [45]. A number of observations suggest, in contrast, that BACE2 would function in vivo as an antiamyloid protein that would limit the amount of $A \beta$ generated by BACE1. Such a property would be explained by the capacity of BACE2 to cleave APP within the $A \beta$ region. In fact both BACE1 and BACE2 cleave APP at internal sites within the A $\beta$ domain. BACE1 cleaves between tyrosine 10 and glutamic acid 11 ( $\beta 11$ position) and as a consequence of this cleavage an $\mathrm{N}$-terminally truncated $\mathrm{A} \beta$ species is generated that is more prone to aggregation than full-length $A \beta$ [51]. The internal BACE2 cleavage site is between residues phenylalanine 19 and 20 and BACE2 cleavage at this position is more efficient than at the $\beta 1$-site $[45,48,49]$. If BACE2 cleaves preferably at this position in vivo, then BACE2 coexpression with BACE1 would result in decreased $A \beta$ secretion. Indeed it has been shown that BACE2 overexpression reduces $A \beta$ levels $[44-46,48]$ whereas BACE2 downregulation by RNAi elevates A $\beta$ secretion [52]. These observations lead to the suggestion that BACE2 does not function in vivo as a $\beta$-secretase but rather as an $\alpha$-like secretase that precludes $A \beta$ formation [48, 49, 52, 53].

Despite some differences in substrate specificity, BACE1 and BACE2 cleave similar sequences and respond similarly to mutations introduced at the $\beta$-site in APP [45]. It is, therefore, likely that substrate-based inhibitors for BACE1 will also affect BACE2 function. This has important implications from a therapeutic point of view. On the one hand, if BACE2 negatively regulates $A \beta$ levels, its nonselective inhibition could counteract the effect of BACE1 inhibition. On the other hand, although the natural substrate(s) for BACE2 are not known, the fact that the mRNA is widely expressed in fetal and adult tissues suggests it might fulfill essential functions. Moreover, whereas long-term BACE1 disruption does not seem to be associated with any gross phenotypic alteration, the physiological consequences of blocking both BACEs are thus far not known. BACE1 and BACE2 might process common substrates in vivo that have not yet been identified and this overlapping function(s) might be unique to these enzymes. The generation of BACE2- and BACE1/BACE2deficient mice will help to address these questions.

\section{Alternative Approaches for BACE1 Modulation}

Alternatively to the nonselective inhibition of BACE1 activity, strategies can be envisioned that may target other aspects of BACE1 metabolism. Considerable progress has been made in our understanding of BACE1 biology since its initial discovery at the end of 1999 [3-6, 54]. In particular, some modes of modulating BACE1 protein levels as well as enzymatic activity have been proposed that might operate in vivo.

BACE1 protein levels and activity are increased in brains of patients with $\mathrm{AD}$ [55-59]; however, the levels of BACE1 transcript seem to be comparable in AD and nondemented controls [56, 60-62]. This suggests that BACE1 expression is regulated posttranscriptionally through a mechanism that is altered in AD. In this respect, the BACE1 transcript contains a 5'-untranslated region (5'UTR) quite unusual for a cellular mRNA. It is more than 400 nucleotides long, contains three short open reading 
frames and has a high GC content and hence the potential to fold into a stable secondary structure [63]. A ribosomeshunting mechanism has been proposed to explain how the translational machinery can access the BACE1 start codon. Ribosome shunting involves the recruitment of ribosomes in a cap-dependent manner and their subsequent nonlinear migration in which part of the $5^{\prime}-\mathrm{UTR}$ is skipped and ribosomes are directly translocated to a site at or close to the start codon of the major open reading frame [64]. The efficiency of shunting seems to be cell type-dependent, suggesting that cell-specific factors are involved in the modulation of BACE1 mRNA translation and raising the possibility that the process is altered in AD [63]. Identifying the mechanism of BACE1 mRNA translation and the factor(s) involved might reveal novel therapeutic targets to control BACE1 expression.

The increase in BACE1 protein observed in brains of AD patients can alternatively be explained by a decrease in protein turnover. There is thus far no solid indication that BACE1 protein is stabilized in AD brains, but a hypothesis can be drawn based on some data from cell culture studies. BACE1 is a rather stable protein with a half-life of about $16 \mathrm{~h}[65,66]$. Higher levels of the lipid second messenger ceramide in cultured cells led to stabilization of BACE1, which in turn resulted in an increase in BACE1-dependent APP products [66]. Because ceramide controls several biochemical events and its levels are elevated in AD brains, the authors propose that ceramide regulates $A \beta$ generation in vivo by affecting the steadystate levels of BACE1 protein. Although more data are required to support this conclusion, the possibility that a signal transduction pathway having ceramide as second messenger can control BACE1 stability is quite appealing. Clearly further research is needed to identify the components of such a pathway and their modes of regulation.

In addition to the modulation of the levels of BACE1 protein, factors that directly affect enzyme activity have also been identified. Several lines of evidence suggest that $\beta$-secretase cleavage of APP takes place in rafts, specialized membrane microdomains rich in cholesterol and sphingolipids. First, cholesterol depletion that results in raft disruption caused a drastic decrease of $\beta$-cleavage in hippocampal neurons [67] and a strong increase of $\alpha$ cleavage in various peripheral and neural cell lines [68]. Conversely, exposure of neurons and glial cells to cholesterol decreased $\alpha$-secretase-mediated cleavage of APP [69]. Second, BACE1 protein has been shown to localize partially into rafts [70]. Finally, increasing the association of BACE1 with lipid rafts by either artificially adding a GPI anchor at the C-terminus of BACE1 ectodomain [71] or by antibody cross-linking [72] was sufficient to stimulate $\beta$-processing. Therefore, affecting the association of BACE1 with rafts appears as an alternative to modulate the efficiency of $\beta$-cleavage. This could be theoretically achieved in an indirect way by modulating cholesterol levels in the brain, and indeed cholesterol-lowering drugs are already being tested in clinical trials. The rational for using such drugs came originally from several epidemiological studies that showed a correlation between high blood cholesterol levels and a higher risk of developing AD [73-75]. Moreover, patients that have been treated with cholesterol-lowering statins were somehow protected against the disease $[76,77]$. The protective role of statins in $\mathrm{AD}$, although not definitively demonstrated, could then be the consequence of their indirect effect on BACE1 activity. An alternative and more direct way of modulating BACE1 compartmentalization into lipid rafts could theoretically be achieved via modulation of its interaction with proteins responsible for the localization of BACE1 into these microdomains. Although very speculative at this stage, at least two proteins have been proposed to play such a role: phospholipid scramblase 1 [78] and a GPIanchored protein [79].

A novel and promising approach to control BACE1 activity has recently been described. BACE1 has been shown to bind to heparan sulfates (HS) both in vivo and in vitro and this binding resulted in inhibition of enzyme activity [80]. The inhibitory properties of the HS depended on the saccharide size and specific structural characteristics. HS inhibition in cultured cells was specific for $\beta$-cleavage of APP since no effect on $\alpha$-cleavage was detected. The authors could show that HS function by blocking the access of the substrate to the enzyme's active site. Interestingly, inhibition of cellular HS synthesis resulted in a concomitant increase in BACE1 activity. These data are preliminary and at present far from practical therapeutic applications, but the possibility of using a natural, direct inhibitor to control BACE1 function definitively deserves further investigation.

\section{Perspectives}

The activity of BACE1 and PS is required to generate the pathogenic $A \beta$ peptide that accumulates in the brain of AD patients. Clearly, blocking their activities appears to be a promising therapy to treat the disease. Transgenic mouse models in which the genes encoding the secretases have been ablated offer an invaluable tool, on the one hand, to gain more insights into the biological function of 
these proteases and, on the other hand, to predict the consequences that might be associated with enzyme inhibition in vivo.

Genetic ablation of the PS genes in mice helped to identify the function of these enzymes in the Notch signalling pathway as well as their absolute requirement for the cleavage of Notch and APP within their transmembrane regions. The biological roles of Nicastrin, Pen-2 and Aph-1 as components of $\gamma$-secretase or their possible extra $\gamma$-secretase function remain to be determined. Several paralogs and alternatively spliced variants of at least PS and Aph-1 have been identified suggesting that $\gamma$-secretase is not an homogenous activity and the availability of mice deficient in $\gamma$-secretase components will help address these issues. Nicastrin- and Pen-2-deficient mice have been generated and they exhibit a phenotype consistent with inhibition of the Notch pathway. We are now awaiting the data for Aph-1-deficient mice.

The absence of any gross phenotype in BACE1 null mice converts this enzyme into a promising drug target. Pharmacologic inhibition of BACE1 does not appear, however, as straightforward as predicted. Moreover, ac- tive site inhibitors are likely to affect in addition BACE2 function. The generation of BACE2 and BACE1/BACE2 double knockout mice is, therefore, crucial to help us predict the consequences of blocking BACE function in vivo and to gain more insights into the biological functions of these two proteases.

Other alternatives to the active site inhibitors for PS and BACE1 can be envisioned that target other aspects of the enzyme metabolism, including for example their interaction with the substrate, their localization in specific subcellular sites where cleavage takes place or the modulation of the expression of the enzymes. Preliminary data that such approaches are feasible are available and energy should be dedicated to their further investigation.

\section{Acknowledgement}

This research was supported by the European Union under the programme 'Quality of Life and Management of Living Resources', Key Action 3 'The Cell Factory', Contract No. QLK3-CT-200102362 .

\section{References}

$>1$ Vassar R: Beta-secretase (BACE) as a drug target for Alzheimer's disease. Adv Drug Deliv Rev 2002;54:1589-1602.

$\checkmark 2$ Annaert W, Cupers P, Saftig P, De Strooper B: Presenilin function in APP processing. Ann NY Acad Sci 2000;920:158-164.

$\checkmark 3$ Hussain I, Powell D, Howlett DR, Tew DG, Meek TD, Chapman C, Gloger IS, Murphy KE, Southan CD, Ryan DM, Smith TS, Simmons DL, Walsh FS, Dingwall C, Christie G: Identification of a novel aspartic protease (Asp 2) as beta-secretase. Mol Cell Neurosci 1999;14: 419-427.

-4 Sinha S, Anderson JP, Barbour R, Basi GS, Caccavello R, Davis D, Doan M, Dovey HF, Frigon N, Hong J, Jacobson-Croak K, Jewett N, Keim P, Knops J, Lieberburg I, Power M, Tan H, Tatsuno G, Tung J, Schenk D, Seubert P, Suomensaari SM, Wang S, Walker D, John V: Purification and cloning of amyloid precursor protein beta-secretase from human brain. Nature 1999:402:537-540.

$\checkmark 5$ Vassar R, Bennett BD, Babu-Khan S, Kahn S, Mendiaz EA, Denis P, Teplow DB, Ross S Amarante P, Loeloff R, Luo Y, Fisher S, Fuller J, Edenson S, Lile J, Jarosinski MA, Biere AL, Curran E, Burgess T, Louis JC, Collins F, Treanor J, Rogers G, Citron M: Beta-secretase cleavage of Alzheimer's amyloid precursor protein by the transmembrane aspartic protease BACE. Science 1999;286:735-741.
-6 Yan R, Bienkowski MJ, Shuck ME, Miao H, Tory MC, Pauley AM, Brashier JR, Stratman NC, Mathews WR, Buhl AE, Carter DB, Tomasselli AG, Parodi LA, Heinrikson RL, Gurney ME: Membrane-anchored aspartyl protease with Alzheimer's disease beta-secretase activity. Nature 1999;402:533-537.

$>7$ De Strooper B, Saftig P, Craessaerts K, Vanderstichele H, Guhde G, Annaert W, Von Figura K, Van Leuven F: Deficiency of presenilin-1 inhibits the normal cleavage of amyloid precursor protein. Nature 1998:391:387-390.

$>8$ Strooper BD, Annaert W: Presenilins and the intramembrane proteolysis of proteins: Facts and fiction. Nat Cell Biol 2001;3:E221-225.

$\checkmark 9$ Brown MS, Ye J, Rawson RB, Goldstein JL: Regulated intramembrane proteolysis: A control mechanism conserved from bacteria to humans. Cell 2000;100:391-398.

10 Martoglio B, Golde TE: Intramembrane-cleaving aspartic proteases and disease: Presenilins, signal peptide peptidase and their homologs. Hum Mol Genet 2003;12/2:R201-206.

11 Urban S, Freeman M: Intramembrane proteolysis controls diverse signalling pathways throughout evolution. Curr Opin Genet Dev 2002;12:512-518.
12 Yu G, Nishimura M, Arawaka S, Levitan D, Zhang L, Tandon A, Song YQ, Rogaeva E, Chen F, Kawarai T, Supala A, Levesque L, Yu H, Yang DS, Holmes E, Milman P, Liang Y, Zhang DM, Xu DH, Sato C, Rogaev E, Smith M, Janus C, Zhang Y, Aebersold R, Farrer LS, Sorbi S, Bruni A, Fraser P, St George-Hyslop P: Nicastrin modulates presenilin-mediated notch/glp-1 signal transduction and betaAPP processing. Nature 2000;407:48-54.

13 Francis R, McGrath G, Zhang J, Ruddy DA, Sym M, Apfeld J, Nicoll M, Maxwell M, Hai B, Ellis MC, Parks AL, Xu W, Li J, Gurney M, Myers RL, Himes CS, Hiebsch R, Ruble C, Nye JS, Curtis D: aph-1 and pen-2 are required for Notch pathway signaling, gamma-secretase cleavage of betaAPP, and presenilin protein accumulation. Dev Cell 2002;3:85-97.

14 Goutte C, Tsunozaki M, Hale VA, Priess JR: APH-1 is a multipass membrane protein essential for the Notch signaling pathway in Caenorhabditis elegans embryos. Proc Natl Acad Sci USA 2002;99:775-779.

15 Edbauer D, Winkler E, Regula JT, Pesold B, Steiner H, Haass C: Reconstitution of gammasecretase activity. Nat Cell Biol 2003;5:486488.

16 De Strooper B: Aph-1, Pen-2, and nicastrin with presenilin generate an active gammasecretase complex. Neuron 2003;38:9-12. 
17 Kimberly WT, LaVoie MJ, Ostaszewski BL, Ye W, Wolfe MS, Selkoe DJ: Gamma-secretase is a membrane protein complex comprised of presenilin, nicastrin, Aph-1, and Pen-2. Proc Natl Acad Sci USA 2003;100:6382-6387.

18 Haass C, Steiner H: Alzheimer disease gammasecretase: A complex story of GxGD-type presenilin proteases. Trends Cell Biol 2002;12: 556-562.

19 Xia W, Wolfe MS: Intramembrane proteolysis by presenilin and presenilin-like proteases. J Cell Sci 2003;116:2839-2844.

20 Black RA, White JM: ADAMs: Focus on the protease domain. Curr Opin Cell Biol 1998;10: 654-659.

-21 Primakoff P, Myles DG: The ADAM gene family: Surface proteins with adhesion and protease activity. Trends Genet 2000;16:8387.

-22 Schlöndorff J, Blobel CP: Metalloprotease-disintegrins: Modular proteins capable of promoting cell-cell interactions and triggering signals by protein-ectodomain shedding. J Cell Sci 1999;112:3603-3617.

23 Selkoe DJ: Notch and presenilins in vertebrates and invertebrates: Implications for neuronal development and degeneration. Curr Opin Neurobiol 2000; 10:50-57.

-24 Tournoy J, Bossuyt X, Snellinx A, Regent M, Garmyn M, Serneels L, Saftig P, Craessaerts K, De Strooper B, Hartmann D: Partial loss of presenilins causes seborrheic keratosis and autoimmune disease in mice. Hum Mol Genet 2004;13:1321-1331.

-25 Hadland BK, Manley NR, Su D, Longmore GD, Moore CL, Wolfe MS, Schroeter EH, Kopan R: Gamma-secretase inhibitors repress thymocyte development. Proc Natl Acad Sci USA 2004;98:7487-7491.

-26 Doerfler P, Shearman MS, Perlmutter RM: Presenilin-dependent gamma-secretase activity modulates thymocyte development. Proc Natl Acad Sci USA 2001;98:9312-9317.

-27 Sestan N, Artavanis-Tsakonas S, Rakic P: Contact-dependent inhibition of cortical neurite growth mediated by notch signaling. Science 1999;286:741-746.

-28 Wong GT, Manfra D, Poulet FM, Zhang Q, Josien H, Bara T, Engstrom L, Pinzon-Ortiz MC, Fine JS, Lee HJ, Zhang L, Higgins GA, Parker EM: Chronic treatment with the gamma-secretase inhibitor LY-411,575 inhibits Abeta production and alters lymphopoiesis and intestinal cell differentiation. J Biol Chem 2004;279:12876-12882.

-29 Cai H, Wang Y, McCarthy D, Wen H, Borchelt DR, Price DL, Wong PC: BACE1 is the major beta-secretase for generation of Abeta peptides by neurons. Nat Neurosci 2001;4:233-234.

- 30 Roberds SL, Anderson J, Basi G, Bienkowski MJ, Branstetter DG, Chen KS, Freedman SB, Frigon NL, Games D, Hu K, Johnson-Wood K, Kappenman KE, Kawabe TT, Kola I, Kuehn R, Lee M, Liu W, Motter R, Nichols NF, Power M, Robertson DW, Schenk D, Schoor M, Shopp GM, Shuck ME, Sinha S, Svensson KA, Tatsuno G, Tintrup H, Wijsman J, Wright S, McConlogue L: BACE knockout mice are healthy despite lacking the primary beta-secre- tase activity in brain: Implications for Alzheimer's disease therapeutics. Hum Mol Genet 2001;10:1317-1324.

-31 Luo Y, Bolon B, Kahn S, Bennett BD, BabuKhan S, Denis P, Fan W, Kha H, Zhang J, Gong Y, Martin L, Louis JC, Yan Q, Richards WG, Citron M, Vassar R: Mice deficient in BACE1, the Alzheimer's beta-secretase, have normal phenotype and abolished beta-amyloid generation. Nat Neurosci 2001;4:231-232.

32 Luo Y, Bolon B, Damore MA, Fitzpatrick D, Liu H, Zhang J, Yan Q, Vassar R, Citron M: BACE1 (beta-secretase) knockout mice do not acquire compensatory gene expression changes or develop neural lesions over time. Neurobiol Dis 2003; 14:81-88.

33 Harrison SM, Harper AJ, Hawkins J, Duddy G, Grau E, Pugh PL, Winter PH, Shilliam CS, Hughes ZA, Dawson LA, Gonzalez MI, Upton $\mathrm{N}$, Pangalos MN, Dingwall C: BACE1 (betasecretase) transgenic and knockout mice: Identification of neurochemical deficits and behavioral changes. Mol Cell Neurosci 2003;24:646655.

34 Ohno M, Sametsky EA, Younkin LH, Oakley H, Younkin SG, Citron M, Vassar R, Disterhoft JF: BACE1 deficiency rescues memory deficits and cholinergic dysfunction in a mouse model of Alzheimer's disease. Neuron 2004;41: 27-33.

>35 Capell A, Meyn L, Fluhrer R, Teplow DB, Walter J, Haass C: Apical sorting of beta-secretase limits amyloid beta-peptide production. J Biol Chem 2002;277:5637-5643.

36 Daugherty BL, Green SA: Endosomal sorting of amyloid precursor protein-P-selectin chimeras influences secretase processing. Traffic 2001;2:908-916.

-37 Tomasselli AG, Qahwash I, Emmons TL, Lu Y, Leone JW, Lull JM, Fok KF, Bannow CA, Smith CW, Bienkowski MJ, Heinrikson RL, Yan R: Employing a superior BACE1 cleavage sequence to probe cellular APP processing. $\mathrm{J}$ Neurochem 2003;84:1006-1017.

38 Lichtenthaler SF, Dominguez DI, Westmeyer GG, Reiss K, Haass C, Saftig P, De Strooper B, Seed B: The cell adhesion protein P-selectin glycoprotein ligand-1 is a substrate for the aspartyl protease BACE1. J Biol Chem 2003;278: 48713-48719.

39 Kitazume S, Tachida Y, Oka R, Shirotani K, Saido TC, Hashimoto Y: Alzheimer's betasecretase, beta-site amyloid precursor proteincleaving enzyme, is responsible for cleavage secretion of a Golgi-resident sialyltransferase. Proc Natl Acad Sci USA 2001;98:1355413559.

40 Hennet T, Chui D, Paulson JC, Marth JD: Immune regulation by the ST6Gal sialyltransferase. Proc Natl Acad Sci USA 1998;95:45044509.

41 Hirata T, Merrill-Skoloff G, Aab M, Yang J, Furie BC, Furie B: P-selectin glycoprotein ligand 1 (PSGL-1) is a physiological ligand for E-selectin in mediating $\mathrm{T}$ helper 1 lymphocyte migration. J Exp Med 2000;192:1669-1676.
42 Yang J, Hirata T, Croce K, Merrill-Skoloff G, Tchernychev B, Williams E, Flaumenhaft R, Furie BC, Furie B: Targeted gene disruption demonstrates that P-selectin glycoprotein ligand 1 (PSGL-1) is required for P-selectinmediated but not E-selectin-mediated neutrophil rolling and migration. J Exp Med 1999; 190:1769-1782.

43 Acquati F, Accarino M, Nucci C, Fumagalli P, Jovine L, Ottolenghi S, Taramelli R: The gene encoding DRAP (BACE2), a glycosylated transmembrane protein of the aspartic protease family, maps to the down critical region. FEBS Lett 2000;468:59-64.

44 Hussain I, Powell DJ, Howlett DR, Chapman GA, Gilmour L, Murdock PR, Tew DG, Meek TD, Chapman C, Schneider K, Ratcliffe SJ, Tattersall D, Testa TT, Southan C, Ryan DM, Simmons DL, Walsh FS, Dingwall C, Christie G: ASP1 (BACE2) cleaves the amyloid precursor protein at the beta-secretase site. Mol Cell Neurosci 2000;16:609-619.

45 Farzan M, Schnitzler CE, Vasilieva N, Leung D, Choe H: BACE2, a beta-secretase homolog, cleaves at the beta site and within the amyloidbeta region of the amyloid-beta precursor protein. Proc Natl Acad Sci USA 2000;97:97129717.

46 Bennett BD, Babu-Khan S, Loeloff R, Louis JC, Curran E, Citron M, Vassar R: Expression analysis of BACE2 in brain and peripheral tissues. J Biol Chem 2000;275:20647-20651.

47 Solans A, Estivill X, de La Luna S: A new aspartyl protease on 21q22.3, BACE2, is highly similar to Alzheimer's amyloid precursor protein beta-secretase. Cytogenet Cell Genet 2000; 89:177-184.

48 Yan R, Munzner JB, Shuck ME, Bienkowski MJ: BACE2 functions as an alternative alphasecretase in cells. J Biol Chem 2001;276: 34019-34027.

49 Fluhrer R, Capell A, Westmeyer G, Willem M, Hartung B, Condron MM, Teplow DB, Haass $\mathrm{C}$, Walter $\mathrm{J}$ : A non-amyloidogenic function of BACE-2 in the secretory pathway. J Neurochem 2002;81:1011-1020.

50 Barbiero L, Benussi L, Ghidoni R, Alberici A, Russo C, Schettini G, Pagano SF, Parati EA, Mazzoli F, Nicosia F, Signorini S, Feudatari E, Binetti G: BACE-2 is overexpressed in Down's syndrome. Exp Neurol 2003;182:335-345.

51 Pike CJ, Overman MJ, Cotman CW: Aminoterminal deletions enhance aggregation of betaamyloid peptides in vitro. J Biol Chem 1995; 270:23895-23898.

52 Basi G, Frigon N, Barbour R, Doan T, Gordon G, McConlogue L, Sinha S, Zeller M: Antagonistic effects of BACE1 and BACE2 on Abeta production in cells. J Biol Chem 2003;278: 31512-31520.

53 Wong PC, Price DL, Cai H: The brain's susceptibility to amyloid plaques. Science 2001;293: 1434.

54 Lin X, Koelsch G, Wu S, Downs D, Dashti A, Tang J: Human aspartic protease memapsin 2 cleaves the beta-secretase site of beta-amyloid precursor protein. Proc Natl Acad Sci USA 2000;97:1456-1460. 
-55 Li R, Lindholm K, Yang LB, Yue X, Citron M, Yan R, Beach T, Sue L, Sabbagh M, Cai H, Wong P, Price D, Shen Y: Amyloid beta peptide load is correlated with increased betasecretase activity in sporadic Alzheimer's disease patients. Proc Natl Acad Sci USA 2004; 101:3632-3637.

-56 Holsinger RM, McLean CA, Beyreuther K, Masters CL, Evin G: Increased expression of the amyloid precursor beta-secretase in Alzheimer's disease. Ann Neurol 2002;51:783786.

57 Fukumoto H, Cheung BS, Hyman BT, Irizarry MC: Beta-secretase protein and activity are increased in the neocortex in Alzheimer disease. Arch Neurol 2002;59:1381-1389.

-58 Yang LB, Lindholm K, Yan R, Citron M, Xia W, Yang XL, Beach T, Sue L, Wong P, Price D, Li R, Shen Y: Elevated beta-secretase expression and enzymatic activity detected in sporadic Alzheimer disease. Nat Med 2003;9:3-4.

-59 Tyler SJ, Dawbarn D, Wilcock GK, Allen SJ: Alpha- and beta-secretase: Profound changes in Alzheimer's disease. Biochem Biophys Res Commun 2002;299:373-376.

-60 Yasojima K, McGeer EG, McGeer PL: Relationship between beta amyloid peptide generating molecules and neprilysin in Alzheimer disease and normal brain. Brain Res 2001;919. 115-121.

-61 Preece P, Virley DJ, Costandi M, Coombes R, Moss SJ, Mudge AW, Jazin E, Cairns NJ: Betasecretase (BACE) and GSK-3 mRNA levels in Alzheimer's disease. Brain Res Mol Brain Res 2003;116:155-158.

-62 Gatta LB, Albertini A, Ravid R, Finazzi D: Levels of beta-secretase BACE and alpha-secretase ADAM10 mRNAs in Alzheimer hippocampus. Neuroreport 2002;13:2031-2033.

-63 Rogers GW Jr, Edelman GM, Mauro VP: Differential utilization of upstream AUGs in the beta-secretase mRNA suggests that a shunting mechanism regulates translation. Proc Nat Acad Sci USA 2004;101:2794-2799.
64 Hohn T, Corsten S, Dominguez D, Futterer J, Kirk D, Hemmings-Mieszczak M, Pooggin M, Scharer-Hernandez N, Ryabova L: Shunting is a translation strategy used by plant pararetroviruses (Caulimoviridae). Micron 2001;32:5157.

65 Huse JT, Pijak DS, Leslie GJ, Lee VM, Doms RW: Maturation and endosomal targeting of beta-site amyloid precursor protein-cleaving enzyme. The Alzheimer's disease beta-secretase. J Biol Chem 2000;275:33729-33737.

66 Puglielli L, Ellis BC, Saunders AJ, Kovacs DM: Ceramide stabilizes beta-site amyloid precursor protein-cleaving enzyme 1 and promotes amyloid beta-peptide biogenesis. J Biol Chem 2003;278:19777-19783.

67 Simons M, Keller P, De Strooper B, Beyreuther K, Dotti CG, Simons K: Cholesterol depletion inhibits the generation of beta-amyloid in hippocampal neurons. Proc Natl Acad Sci USA 1998;95:6460-6464.

68 Kojro E, Gimpl G, Lammich S, Marz W, Fahrenholz $\mathrm{F}$ : Low cholesterol stimulates the nonamyloidogenic pathway by its effect on the alpha-secretase ADAM 10. Proc Natl Acad Sci USA 2001;98:5815-5820.

69 Galbete JL, Martin TR, Peressini E, Modena P, Bianchi R, Forloni G: Cholesterol decreases secretion of the secreted form of amyloid precursor protein by interfering with glycosylation in the protein secretory pathway. Biochem $\mathrm{J}$ 2000;348:307-313.

70 Riddell DR, Christie G, Hussain I, Dingwall C: Compartmentalization of beta-secretase (Asp2) into low-buoyant density, noncaveolar lipid rafts. Curr Biol 2001;11:1288-1293.

71 Cordy JM, Hussain I, Dingwall C, Hooper NM, Turner AJ: Exclusively targeting betasecretase to lipid rafts by GPI-anchor addition up-regulates beta-site processing of the amyloid precursor protein. Proc Natl Acad Sci USA 2003; 100:11735-11740.

72 Ehehalt R, Keller P, Haass C, Thiele C, Simons $\mathrm{K}$ : Amyloidogenic processing of the Alzheimer beta-amyloid precursor protein depends on lipid rafts. J Cell Biol 2003;160:113-123.
73 Hofman A, Ott A, Breteler MM, Bots ML, Slooter AJ, van Harskamp F, van Duijn CN, Van Broeckhoven C, Grobbee DE: Atherosclerosis, apolipoprotein $\mathrm{E}$, and prevalence of dementia and Alzheimer's disease in the Rotterdam Study. Lancet 1997;349:151-154.

74 Notkola IL, Sulkava R, Pekkanen J, Erkinjuntti T, Ehnholm C, Kivinen P, Tuomilehto J, Nissinen A: Serum total cholesterol, apolipoprotein E epsilon 4 allele, and Alzheimer's disease. Neuroepidemiology 1998;17:14-20.

75 Kivipelto M, Helkala EL, Hanninen T, Laakso MP, Hallikainen M, Alhainen K, Soininen H, Tuomilehto J, Nissinen A: Midlife vascular risk factors and late-life mild cognitive impairment: A population-based study. Neurology 2001;56:1683-1689.

76 Wolozin B, Kellman W, Ruosseau P, Celesia GG, Siegel G: Decreased prevalence of Alzheimer disease associated with 3-hydroxy-3methyglutaryl coenzyme A reductase inhibitors. Arch Neurol 2000;57:1439-1443.

77 Jick H, Zornberg GL, Jick SS, Seshadri S, Drachman DA: Statins and the risk of dementia. Lancet 2000;356:1627-1631.

78 Kametaka S, Shibata M, Moroe K, Kanamori S, Ohsawa Y, Waguri S, Sims PJ, Emoto K, Umeda M, Uchiyama Y: Identification of phospholipid scramblase 1 as a novel interacting molecule with beta-secretase (beta-site amyloid precursor protein (APP) cleaving enzyme (BACE)). J Biol Chem 2003;278:15239_ 15245.

79 Tun H, Marlow L, Pinnix I, Kinsey R, Sambamurti K: Lipid rafts play an important role in A beta biogenesis by regulating the beta-secretase pathway. J Mol Neurosci 2002;19:31-35.

80 Scholefield Z, Yates EA, Wayne G, Amour A, McDowell W, Turnbull JE: Heparan sulfate regulates amyloid precursor protein processing by BACE1, the Alzheimer's beta-secretase. J Cell Biol 2003;163:97-107.

81 Marjaux E, De Strooper B: Gamma-secretase inhibitors, still in the running as Alzheimer's therapeutics. Drug Discov Today Ther Strategies, in press. 